\title{
KARAKTERISTIK KOMUNITAS NEMATODA DI PADANG GOLF SUKARAME (PGS) BANDAR LAMPUNG
}

\author{
I Gede Swibawa $^{1}$ dan Titik Nur Aeny ${ }^{1}$
}

\begin{abstract}
Characteristic of Nematodes Community at PGS Golf Course Bandar Lampung. Golf course is a unique ecosystem where plant parasitic nematodes inhabit and become important pest because they reduce the quality of the grass. The pest problems on golf course can be indicated by its characteristics of nematode community. Survey on nematodes community at PGS Golf Course Bandar Lampung was conducted from March to December 2004. The objective was to study the characteristics of nematode community in the part of golf courses hole (green, collar, apron, and fairway). Soil samples were taken from five holes each of it consists of green, collar, apron, and fairway, respectiveley. Nematodes extraction was done in Laboratory of Arthropod Pest, Department of Plant Protection University of Lampung. The result showed that at least 50 nematodes genera of 28 families inhabit PGS. The number of plant parasitic nematode genera was higher than the free-living one. The characteristic of nematodes community on green and collar was different than on faiway. Nematode abundance and diversity on green and collar were higher than on fairway. Based on abundance of nematode feeding group, maturity index of free-living nematodes (MI) and that of plant parasitic nematodes (PPI), green and collar part seemed to be more favorable to plant parasitic nematodes than free-living nematodes. The contrary happened for fairway. Four most dominant genera of plant parasitic nematodes on PGS golf course were Helicotylenchus, Hoplolaimus, Criconemella, and Xiphinema.
\end{abstract}

Key words: nematodes community, golf course

\section{PENDAHULUAN}

Nematoda parasit tumbuhan merupakan salah satu OPT penting penyebab turunnya kualitas padang golf. Tidak kurang dari 10 jenis nematoda parasit tumbuhan berasosiasi dengan padang golf dan nematoda ini kerap diberi sebutan "the hidden enemy" bagi padang golf di Amerika Serikat (Sikora et al., 1999). Sementara itu pemantauan Tjahyono (2007) terhadap padang golf di Indonesia mendapatkan tidak kurang dari 7 genus nematoda yang memarasit akar rumput golf. Keberadaan nematoda parasit tumbuhan di padang golf dipengaruhi oleh umur serta kondisi fisika-kimia tanah padang golf (Walker et al., 2002).

Sebagian besar penelitian mengenai nematoda padang golf difokuskan pada aspek-aspek praktis. Kajian yang sering dilakukan di antaranya tentang teknik-teknik pengendalian spesies nematoda parasit tumbuhan tertentu di bagian green, seperti yang dilaporkan oleh Westerdahi, et al. (2005); Crow et al. (2005) dan Walker et al. (2005). Namun demikian, terdapat juga hasil penelitian dasar yang telah dilaporkan, di antaranya mengenai hubungan faktorfaktor lingkungan tanah dengan tingkat populasi nematoda parasit tumbuhan (Walker et al., 2002) dan dampak aplikasi nematoda dan jamur patogen serangga terhadap biota non-target dalam tanah termasuk nematoda (Wang et al., 2001). Karakteristik komunitas nematoda baik nematoda parasit tumbuhan maupun nematoda free-living (nir parasit) di bagianbagian hole padang golf belum banyak dipelajari. Diduga bagian-bagian hole padang golf mempengaruhi komunitas nematoda karena masingmasing bagian ini memiliki sifat dan rancangan pembuatannya yang khas serta jenis rumput dan intensitas perawatan yang berbeda.

Penelitian ini bertujuan untuk mempelajari karakteristik komunitas nematoda tanah di bagianbagian utama hole padang golf yaitu green, collar, apron, dan fairway. Hasil penelitian ini diharapkan dapat menjadi bahan pertimbangan bagi pihak manajemen padang golf dalam mengambil keputusan pengelolaan nematoda parasit tumbuhan.

\section{METODE PENELITIAN}

Penelitian ini dilaksanakan mulai bulan Maret sampai Desember 2004. Kegiatan penelitian meliputi pengambilan sampel tanah di Padang Golf Sukarame (PGS) Bandar Lampung pada bulan April serta

\footnotetext{
$\overline{{ }^{1} \text { Jurusan Proteksi Tanaman, Fakultas Pertanian, Universitas Lampung }}$ Jl. Prof. Sumantri Brojonegoro No. 1 Bandar Lampung 35145
} 
ektraksi dan identifikasi nematoda di Laboratorium Hama Artropoda Jurusan Proteksi Tanaman Fakultas Pertanian Universitas Lampung.

Padang Golf Sukarame (PGS) yang merupakan konversi dari perkebunan karet dan telah berumur 32 tahun, mencakup lahan seluas 45 hektar dan memiliki 18 hole. Setiap hole di PGS ini mengandung empat bagian utama yaitu green, collar, apron, dan fairway dengan karakterisitik dan sifat fisika-kimia tanahnya disajikan pada Tabel 1 dan Gambar 1

Terok tanah dari lima hole dan masing-masing bagiannya diambil pada bulan April sebanyak empat kali, yaitu minggu I, II, III, dan IV setelah pemupukan dan aplikasi pestisida (aplikasi pupuk NPK dan pestisida carbofuran hanya dilakukan di bagian green dan collar). Dari setiap bagian ini terok tanah diambil menggunakan pisau cukil pada kedalaman $0-15 \mathrm{~cm}$ dari lima titik terok dengan teknik penerokan sistematik random yang disesuaikan dengan bentuk lahan agar dapat mewakili populasi di setiap bagian hole. Pada bagian green, terok diambil secara diagonal, pada bagian colar dan apron terok diambil secara melingkar, sedangkan pada bagian fairway terok diambil secara zig-zag. Terok tanah dari kelima titik dikomposit dan diambil sebanyak $\pm 0,5 \mathrm{~kg}$, disimpan dalam kantong plastik, dan selanjutnya diekstraksi di laboratorium. Selama penerokan, terok tanah diupayakan terhindar dari dedahan cahaya matahari langsung.

Ekstraksi nematoda dilakukan terhadap $100 \mathrm{cc}$ tanah menggunakan metode penyaringan dan sentrifugasi dengan larutan gula (Dropkin, 1992). Suspensi nematoda hasil ekstraksi dijadikan $100 \mathrm{ml}$. Penghitungan nematoda dilakukan di bawah mikroskop bedah stereo dengan perbesaran 10-40 kali untuk setiap $10 \mathrm{ml}$ suspensi. Kelimpahan nematoda merupakan rata-rata dari 3 kali penghitungan yang dikalikan 10. Dari setiap suspensi nematoda terok, \pm 100 individu nematoda diambil secara acak menggunakan kait untuk dibuat preparat semipermanen menggunakan gelas objek berukuran $2 \mathrm{~cm} \mathrm{x}$ $6 \mathrm{~cm}$ untuk keperluan identifikasi.

Nematoda diidentifikasi sampai tingkat genus berdasarkan ciri morfologi yang teramati di bawah mikroskop majemuk dengan perbesaran 400 - 1000 kali. Indentifikasi nematoda menggunakan kunci identifikasi dan determinasi Goodey (1963), Mai dan Lyon (1975), Siddiqi (1986) serta referensi pendukung lainnya. Berdasarkan Yeat et al. (1993) takson famili nematoda digolongkan berdasarkan atas kelompok makan, yaitu nematoda parasit tumbuhan, nematoda pemakan jamur, nematoda pemakan bakteri, nematoda pemakan substrat, nematoda pemakan hewan, nematoda pemakan mikroba eukariotik uniselular, nematoda parasit hewan, dan nematoda omnivora. Nematoda nir-parasit tumbuhan lazimnya disebut nematoda hidup bebas (free-living nematodes).

Genus nematoda yang ditemukan dari setiap terok tanah di PGS dicatat. Kelimpahan nematoda yang dimaksudkan dalam penelitian ini meliputi kelimpahan seluruh genus dan kelimpahan per kelompok makan nematoda tiap 100 cc tanah. Kelimpahan per kelompok makan nematoda diperoleh dengan cara mengalikan kelimpahan relatif masingmasing genus dalam kelompok makan dengan kelimpahan seluruh genus nematoda. Karakteristik komunitas nematoda yang diamati adalah keragaman genus, maturitas, dan kelimpahan seluruh nematoda. Keragaman diukur berdasarkan jumlah genus dan indeks keragaman Shannon-Wiener $\left(\mathrm{H}^{\prime}\right)$ genus nematoda $\left(\mathrm{H}^{\prime}=-\sum \mathrm{p} i \mathrm{x} \ln \mathrm{p} i\right.$; $\mathrm{p} i$ merupakan proporsi genus ke $i$ ). Maturitas nematoda dihitung berdasarkan indeks maturitas untuk nematoda free-living (MI) dan indeks maturitas untuk nematoda parasit tumbuhan (PPI) untuk setiap terok. $\mathrm{MI}=\sum \mathrm{v} i \mathrm{x} f i ;(\mathrm{v} i=$ nilai colonizer-persister (c-p) dari 1-5 untuk genus ke $i$, dan $\mathrm{f} i=$ frekuensi relatif genus ke $i$ ). Nematoda tertentu bersifat colonizer yaitu yang pertumbuhannya berstrategi $r$ (dalam arti luas) memiliki nilai c-p $=1$, nematoda yang bersifat persister yaitu yang pertumbuhannya berstrategi $\mathrm{K}$ (dalam arti luas) bernilai $\mathrm{c}-\mathrm{p}=5$, sedangkan nematoda lainnya bersifat diantaranya sehingga bernilai $c-p=2,3$, atau 4 (Bongers, 1990). Nilai MI mengukur adanya gangguan, nilai lebih rendah mengindikasikan ekosistem yang lebih terganggu sedangkan nilai lebih tinggi menunjukkan ekosistem yang kurang terganggu. PPI dihitung menggunakan formula yang sama dengan penghitungan MI tetapi mengabaikan nematoda free-living, nilai colonizer-persister (c-p) genus-genus nematoda parasit tumbuhan berkisar 2-5, tidak ada genus nematoda parasit tumbuhan yang bersifat colonizer dengan nilai 1. Peningkatan PPI mengindikasikan produktivitas lahan (terutama akar tumbuhan) yang meningkat (Freckman \& Ettema, 1993). 
Tabel 1. Karakteristik dan sifat fisika-kimia tanah pada bagian-bagian utama hole PGS, Bandar Lampung

\begin{tabular}{|c|c|}
\hline $\begin{array}{c}\text { Bagian-bagian } \\
\text { hole }\end{array}$ & Karakteristik dan sifat fisika-kimia tanah \\
\hline green & $\begin{array}{l}\text { Berbentuk lingkaran atau oval dengan diameter } \pm 15 \mathrm{~m} \text {, ditanami rumput bermuda } \\
\text { (Cynodon dactilon.), terdapat sebuah hole (lubang tempat memasukkan bola), dirancang } \\
\text { khusus dengan penutupan tanah berpasir, kondisinya dijaga agar tetap baik melalui } \\
\text { perawatan intensif yang meliputi: (1) pemangkasan rumput setiap hari untuk } \\
\text { mempertahankan ketinggian permukaan rumput } 5 \mathrm{~mm} \text {, (2) penyiraman dua kali se hari } \\
\text { yaitu pagi dan sore, (3) pemupukan NPK dua kali setiap bulan, (4) pengenatan (top- } \\
\text { dressing) dengan pasir halus sekali setiap bulan, (5) pengendaian OPT dengan aplikasi } \\
\text { pestisida semprot dua kali setiap bulan dan aplikasi pestisida carbofuran granular sekali } \\
\text { setiap bulan, serta (6) pengendaian gulma secara manual setiap saat. Sifat fisika-kimia } \\
\text { tanah: kandungan pasir }(85,22 \%) \text {, debu }(0,49 \%) \text {, liat }(14,29 \%) \text {, kadar air }(22,90 \%) \text {, dan } \\
\text { nisbah C/N }(9,31) \text {. }\end{array}$ \\
\hline
\end{tabular}

Berbentuk sabuk (lebar $\pm 2 \mathrm{~m}$ ) melingkar di bagian pinggir luar green, ditanami rumput bermuda (Cynodon dactilon), dirancang khusus sebagai bagian tepi green, perawatan intensif bagian ini meliputi: (1) pemangkasan rumput setiap hari untuk mempertahankan ketinggian permukaan rumput $8 \mathrm{~mm}$, (2) penyiraman dua kali sehari yaitu pagi dan sore,

collar (3) pemupukan NPK dua kali setiap bulan, (4) pengenatan (top-dressing) dengan pasir halus sekali setiap bulan, (5) pengendalian OPT dengan aplikasi pestisda semprot dua kali setiap bulan dan aplikasi pestisida carbofuran granular sekali setiap bulan, serta (6) pengendaian gulma secara manual setiap saat. Sifat fisika-kimia tanah: mengandung pasir $(86,28 \%)$, debu (1,33\%), liat (12,39\%), kadar air $(20,30 \%)$, dan nisbah C/N $(9,52)$.

Berbentuk melingkar di sekeliling luar collar (lebar $\pm 10 \mathrm{~m}$ ), ditumbuhi beberapa jenis rumput, rumput yang dominan yaitu jenis kerbau/pahitan (Paspalum conjugatum), apron perawatan meliputi pemangkasan setiap tiga hari sekali untuk mempertahankan ketinggian rumput $20 \mathrm{~mm}$. Sifat fisika-kimia tanah: mengandung pasir $(95,46 \%)$, debu $(0,79 \%)$, liat $(3,84 \%)$, kadar air $(22,60 \%)$, dan nisbah C/N $(10,95)$.

Merupakan bagian terluas dari lapangan golf di luar bagian-bagian yang lainnya, ditumbuhi beberapa jenis rumput, rumput yang dominan yaitu jenis kerbau/pahitan (Paspalum conjugatum), perawatannya meliputi pemangkasan setiap tiga hari sekali fairway untuk mempertahankan ketinggian rumput $100-120 \mathrm{~mm}$. Sifat fisika-kimia tanah: mengandung pasir $(68,75 \%)$, debu $(5,56 \%)$, liat $(15,69 \%)$, kadar air $(24,30 \%)$, dan nisbah $\mathrm{C} / \mathrm{N}(9,57)$.

Keterangan : Sumber informasi berasal dari pihak manajemen PGS. Analisis tanah dilakukan di Laboratorium Ilmu Tanah Fakultas Pertanian Unila 


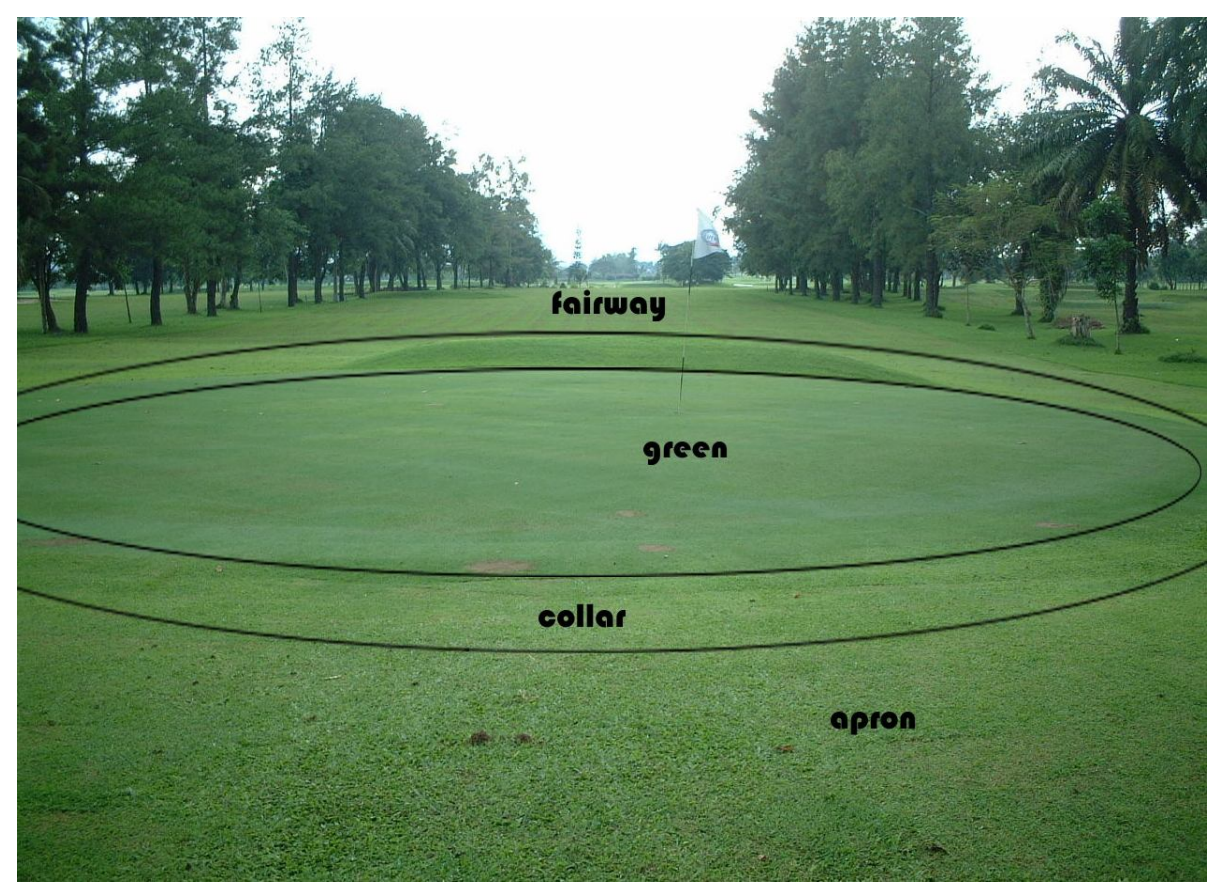

Gambar 1. Salah satu hole dan bagian-bagian utamanya PGS Bandar Lampung

Analisis ragam dilakukan terhadap kelimpahan seluruh genus, kelimpahan per kelompok makan, keragaman genus dan maturitas nematoda. Nilai tengah kelimpahan per kelompok makan, keragaman genus dan maturitas nematoda diuji dengan uji Duncan menggunakan program SAS for Windows $\mathrm{v}$ 6.12 (SAS Institute Inc., 1998). Semua pengujian statistik menggunakan taraf nyata $\mathrm{P}<0,05$ atau $\mathrm{P}<$ 0,01 .

\section{HASIL DAN PEMBAHASAN}

Genus nematoda yang ditemukan. Hasil survei komunitas nematoda di PGS disajikan pada Tabel 2. Pada Tabel 2 tersebut tampak bahwa PGS dihuni oleh tidak kurang dari 50 genus nematoda yang terkelompokkan ke dalam 28 famili. Jumlah genus di PGS ini dapat dikatakan tinggi bila dibandingkan dengan temuan Yeates (1996) yang melaporkan bahwa lahan (hutan, semak dan padang rumput) di Selandia Baru mengandung 44 genus nematoda tanah.

Berdasarkan takson famili, komunitas nematoda di PGS memilki nilai c-p yaitu 1-5 (kecuali Cryptonchidae yang belum diketahui nilai c-p nya) dan meliputi 6 kelompok makan. Nilai c-p merupakan pembobotan berdasarkan strategi hidup nematoda. Nematoda tanah dapat dikelompokkan ke dalam: (1) nematoda colonizer yaitu nematoda yang memiliki strategi $r$ (dalam arti luas), memproduksi telur berukuran kecil, mengeksploitasi lingkungan yang kaya nutrisi secara cepat, dan (2) nematoda kelompok persister yaitu nematoda yang memiliki strategi K (dalam arti luas) dan bereaksi lambat terhadap lingkungan yang mengandung makanan melimpah (Bongers dan Bongers, 1998). Berdasarkan nilai c-p, komunitas nematoda di PGS didominasi oleh nematoda yang memiliki strategi pertumbuhan populasi moderat karena sebagian besar genus memiliki nilai c-p yaitu 2, 3, dan 4 dan sebagian kecil merupakan genus yang memiliki nilai c-p yaitu 1 dan 5. Menurut McSorley dan Frederick (1999) suksesi ekosistem dalam tanah dipengaruhi oleh kandungan bahan organik tanah. Nematoda pemakan bakteri (bernilai c-p rendah) umumnya segera muncul dan dominan ketika lahan diaplikasi dengan bahan organik, sedangkan nematoda kelompok omnivora dan pemakan hewan (bernilai c-p tinggi) muncul enam bulan kemudian. Diduga umur PGS yang telah mencapai 35 tahun mempengaruhi suksesi komunitas nematoda ini. 
Tabel 2. Genus, famili, nilai c-p, dan kelompok makan nematoda yang ditemukan di bagian-bagain hole PGS Bandar Lampung

\begin{tabular}{|c|c|c|c|c|c|c|c|c|}
\hline \multirow[t]{2}{*}{ No. } & \multirow[t]{2}{*}{ Genus } & \multirow[t]{2}{*}{ Famili } & \multirow{2}{*}{$\begin{array}{c}\text { Nilai } \\
\text { c-p } \\
*\end{array}$} & \multirow{2}{*}{$\begin{array}{l}\text { Kelompok } \\
\text { Makan** }\end{array}$} & \multicolumn{4}{|c|}{$\begin{array}{l}\text { Proporsi genus nematoda di } \\
\text { bagian - bagian hole }(\%)\end{array}$} \\
\hline & & & & & Green & Collar & Apron & Fairway \\
\hline 1 & Belonolaimus & Dolichodoridae & 3 & 1 & 0,0 & 0,0 & 0,0 & 0,9 \\
\hline 2 & Criconemella & Criconematidae & 3 & 1 & 6,2 & 5,3 & 10,2 & 2,2 \\
\hline 3 & Helicotylenchus & Hoplolaimidae & 3 & 1 & 12,1 & 17,4 & 7,9 & 0,0 \\
\hline 4 & Hemicriconemoides & Criconematidae & 3 & 1 & 0,4 & 1,4 & 9,5 & 0,0 \\
\hline 5 & Hemicycliophora & Criconematidae & 3 & 1 & 0,0 & 0,0 & 0,0 & 0,6 \\
\hline 6 & Hirschmaniella & Pratylenchidae & 3 & 1 & 0,0 & 0,0 & 1,1 & 3,1 \\
\hline 7 & Hoplolaimus & Hoplolaimidae & 3 & 1 & 23,1 & 23,7 & 0,7 & 0,0 \\
\hline 8 & Longidorella & Nordiidae & 4 & 1 & 0,2 & 0,6 & 0,7 & 1,5 \\
\hline 9 & Longidorus & Longidoridae & 5 & 1 & 0,1 & 0,1 & 0,2 & 0,3 \\
\hline 10 & Meloidogyne & Meloidogynidae & 3 & 1 & 0,0 & 0,0 & 1,8 & 0,9 \\
\hline 11 & Miranema & Longidoridae & 5 & 1 & 0,4 & 0,1 & 0,9 & 0,0 \\
\hline 12 & Paralongidorus & Longidoridae & 5 & 1 & 0,0 & 0,0 & 0,2 & 0,0 \\
\hline 13 & Pratylenchus & Pratylenchidae & 3 & 1 & 8,2 & 0,9 & 2,3 & 4,3 \\
\hline 14 & Psilenchus & Psilenchidae & 2 & 1 & 0,0 & 0,0 & 0,7 & 0,0 \\
\hline 15 & Rotylenchus & Hoplolaimidae & 3 & 1 & 3,9 & 2,2 & 2,5 & 4,0 \\
\hline 16 & Scutellonema & Hoplolaimidae & 3 & 1 & 0,0 & 0,4 & 0,0 & 0,0 \\
\hline 17 & Swangeria & Belondiridae & 5 & 1 & 0,0 & 1,9 & 0,0 & 0,0 \\
\hline 18 & Tricodorus & Trichodoridae & 4 & 1 & 0,0 & 0,2 & 0,0 & 0,9 \\
\hline 19 & Tylenchorhynchus & Dolichodoridae & 3 & 1 & 1,4 & 1,4 & 0,2 & 0,6 \\
\hline 20 & Tylenchulus & Tylenchulidae & 2 & 1 & 0,4 & 0,0 & 0,0 & 0,6 \\
\hline 21 & Xiphinema & Longidoridae & 5 & 1 & 4,9 & 12,8 & 9,9 & 3,4 \\
\hline 22 & Aphelenchoides & Aphelencoididae & 2 & 1,2 & 0,3 & 0,6 & 3,4 & 4,9 \\
\hline 23 & Ditylenchus & Anguinidae & 2 & 1,2 & 3,7 & 1,9 & 2,3 & 1,5 \\
\hline 24 & Tylenchus & Tylenchidae & 2 & 1,2 & 0,6 & 1,7 & 2,5 & 6,2 \\
\hline 25 & Pungentus & Dorylaimidae & 4 & $1,5,8$ & 0,0 & 0,0 & 0,5 & 0,0 \\
\hline 26 & Oxydirus & Belondiridae & 5 & 1,8 & 0,2 & 0,1 & 1,1 & 0,0 \\
\hline 27 & Deladenus & Neotylenchidae & 2 & 2 & 0,0 & 0,6 & 0,0 & 0,0 \\
\hline 28 & Paurodontus & Neotylenchidae & 2 & 2,7 & 1,7 & 0,4 & 1,1 & 1,2 \\
\hline 29 & Thada & Neotylenchidae & 2 & 2,7 & 0,0 & 0,1 & 0,0 & 0,0 \\
\hline 30 & Acrobeles & Acrobelidae & 2 & 3 & 0,3 & 1,3 & 0,5 & 0,0 \\
\hline 31 & Aulolaimus & Cryptonchidae & $* * *$ & 3 & 0,0 & 0,0 & 0,5 & 0,0 \\
\hline 32 & Cronogaster & Leptolaimidae & 2 & 3 & 0,0 & 0,3 & 2,7 & 0,0 \\
\hline 33 & Cryptonchus & Cryptonchidae & $* * *$ & 3 & 0,0 & 0,9 & 0,2 & 0,0 \\
\hline 34 & Micronema & Panagrolaimidae & 1 & 3 & 0,9 & 1,1 & 0,0 & 0,6 \\
\hline 35 & Panagrobelus & Panagrolaimidae & 1 & 3 & 0,3 & 0,2 & 0,0 & 0,0 \\
\hline 36 & Panagrolaimus & Panagrolaimidae & 1 & 3 & 10,4 & 5,0 & 9,5 & 15,1 \\
\hline 37 & Plectus & Plectidae & 2 & 3 & 9,3 & 3,8 & 2,3 & 7,1 \\
\hline 38 & Rhabditis & Rhabditidae & 1 & 3 & 5,2 & 5,9 & 5,9 & 18,9 \\
\hline 39 & Teratorcephalus & Teratocephalidae & 3 & 3 & 0,0 & 0,2 & 0,7 & 0,0 \\
\hline 40 & Zeldia & Acrobelidae & 2 & 3 & 2,0 & 0,2 & 0,0 & 0,0 \\
\hline 41 & Anatonchus & Anatonchidae & 4 & 5 & 0,0 & 0,0 & 0,5 & 0,0 \\
\hline
\end{tabular}


Tabel 2. Lanjutan

\begin{tabular}{|c|c|c|c|c|c|c|c|c|}
\hline \multirow[t]{2}{*}{ No. } & \multirow[t]{2}{*}{ Genus } & \multirow[t]{2}{*}{ Famili } & \multirow{2}{*}{$\begin{array}{c}\text { Nilai } \\
\text { c-p } \\
*\end{array}$} & \multirow{2}{*}{$\begin{array}{l}\text { Kelompok } \\
\text { Makan** }\end{array}$} & \multicolumn{4}{|c|}{$\begin{array}{l}\text { Proporsi genus nematoda di } \\
\text { bagian - bagian hole }(\%)\end{array}$} \\
\hline & & & & & Green & Collar & Apron & Fairway \\
\hline 42 & Eudorylaimus & Nordiidae & 4 & 5 & 1,8 & 4,8 & 4,3 & 11,1 \\
\hline 43 & Iotonchus & Mononchidae & 4 & 5 & 0,3 & 0,2 & 4,5 & 2,5 \\
\hline 44 & Mononchus & Mononchidae & 4 & 5 & 0,1 & 0,9 & 0,5 & 0,0 \\
\hline 45 & Mylonchulus & Mononchidae & 4 & 5 & 0,4 & 0,4 & 0,0 & 0,0 \\
\hline 46 & Seinura & Seinuridae & 2 & 5 & 0,0 & 0,1 & 0,0 & 0,0 \\
\hline 47 & Tripyla & Tripylidae & 3 & 5 & 0,0 & 0,3 & 0,0 & 0,0 \\
\hline 48 & Aporcelaimus & Dorylaimidae & 4 & 5,8 & 0,0 & 0,2 & 0,0 & 0,3 \\
\hline 49 & Sectonema & Aporcelaimidae & 5 & 5,8 & 0,0 & 0,0 & 0,7 & 0,0 \\
\hline 50 & Dorylaimus & Dorylaimidae & 4 & 8 & 1,1 & 0,5 & 7,9 & 7,1 \\
\hline
\end{tabular}

Keterangan: Genus dan famili merupakan seluruh nematoda yang ditemukan di PGS

* Nilai c-p (colonizer - persisters) berdasarkan takson famili (Bongers dan Bongers, 1998),

** kelompok makan (Yeat at al., 1993: 1 = parasit tumbuhan, $2=$ pemakan jamur, 3 = pemakan bakteri, $4=$ pemakan substrat, $5=$ pemakan hewan, $6=$ pemakan mikroba eukariotik uniselular, $7=$ fase tertentu sebagai parasit hewan, dan $8=$ omnivora),

$* * *$ = tidak diketahui nilai c-p nya.

Apabila dilihat dari kelompok makan, tampak bahwa nematoda parasit tumbuhan (26 genus) merupakan nematoda yang dominan dibandingkan dengan masing-masing nematoda pemakan jamur (6 genus), nematoda pemakan bakteri (11 genus), nematoda pemakan hewan (10 genus), nematoda parasit hewan ( 2 genus), dan nematoda omnivora (5 genus).

Tidak seluruh genus (50 genus) dapat ditemukan di semua bagian hole PGS. Dari lima hole yang diamati sebanyak 29 genus ditemukan dari bagian green, dan berturut-turut 39, 35, dan 25 genus masing-masing ditemukan dari bagian collar, apron, dan fairway. Beberapa genus mendominasi komunitas nematoda pada bagian-bagian hole PGS. Dari seluruh genus yang ditemukan Helicotylenchus dan Hoplolaimus merupakan dua genus dominan yaitu masing-masing $12,1 \%$ dan $23,1 \%$ di bagian green dan masing-masing $17,4 \%$ dan $23,7 \%$ di bagian collar. Genus Criconemella dan Xiphinema merupakan dua genus dominan yang ditemukan di bagian apron yaitu masing-masing 10,2\% dan 9,9\%. Menurut Sikora et al. (1999), keempat genus nematoda tersebut merupakan hama penting padang rumput bagian green di banyak padang golf di USA. Walker et al. (2002) menambahkan bahwa
Criconemella menjadi OPT penting di $60 \%$ padang golf di Oklahoma USA, sedangkan Helicotylenchus menjadi OPT penting di $30 \%$ padang golf lainnya. Dua genus nematoda dominan di bagian fairway PGS, yaitu Panagrolaimus $(15,1 \%)$ dan Eudorylaimus $(11,1 \%)$, kedua genus nematoda ini adalah nematoda free-living yang berturut-turut merupakan nematoda pemakan bakteri dan nematoda pemakan hewan.

Kelimpahan dan keragaman nematoda. Hasil pengamatan menunjukkan bahwa terjadi penurunan kelimpahan seluruh genus nematoda di bagian-bagian hole PGS dari minggu I sampai minggu IV dalam satu bulannya. Pengamatan pada minggu I dilakukan sehari setelah aplikasi pupuk NPK dan pestisida carbofuran pada bagian green dan collar ( aplikasi pupuk dan pestisida tidak dilakukan di bagian apron dan fairway). Aplikasi pupuk dan pestisida di bagian green dan collar dilakukan secara rutin setiap bulan (lihat Tabel 1).

Kelimpahan seluruh genus nematoda yang turun pada minggu III dan IV dibandingkan dengan minggu I dan II tampaknya tidak berhubungan dengan aplikasi pupuk dan pestisida. Walaupun aplikasi pupuk dan pestisida carbofuran dilakukan di bagian green dan collar, tetapi penurunan kelimpahan seluruh genus 
nematoda terjadi di keempat bagian hole PGS termasuk bagian yang tidak diaplikasi pupuk NPK dan pestisida yaitu apron dan fairway.

Perbedaan karakteristik bagian-bagian hole PGS (lihat Tabel 1) mempengaruhi kelimpahan seluruh genus nematoda $(\mathrm{P}<0,05)$. Pada Gambar 1 tampak bahwa sejak minggu I sampai minggu IV secara konsisten kelimpahan seluruh genus nematoda di green dan collar lebih tinggi daripada kelimpahan seluruh genus nematoda di bagian apron dan fairway. Kelimpahan seluruh genus di bagian green dan collar berkisar $100-300$ individu per100 $\mathrm{cc}$ tanah (setara dengan 1-3 juta individu nematoda tiap $1 \mathrm{~m}^{3}$ tanah) ini cukup tinggi bila dibandingkan dengan temuan Yeates (1996) yaitu kelimpahan nematoda pada padang rumput di Selandia Baru berkisar 1-4,2 juta individu nematoda per $\mathrm{m}^{2}$ tanah.

Kelimpahan seluruh genus nematoda di bagian green dan collar yang lebih tinggi daripada di bagian apron dan fairway diduga disumbang oleh tingginya kelimpahan nematoda parasit tumbuhan. Analisis ragam terhadap kelimpahan relatif per kelompok makan nematoda menunjukkan bahwa hanya nematoda parasit tumbuhan yang dipengaruhi oleh bagian-bagian hole PGS $(\mathrm{P}<0,01)$ tetapi tidak terhadap nematoda free-living (nematoda pemakan bakteri, nematoda pemakan jamur, nematoda pemakan hewan, dan nematoda omnivora) (Tabel 3).

Kelimpahan nematoda parasit tumbuhan di bagian green dan collar yang masing-masing berkisar 91-119 individu per 100 cc tanah lebih tinggi daripada kelimpahan nematoda parasit tumbuhan di bagian apron dan fairway yang masing-masing berkisar 11-36 individu per 100 cc tanah. Kelimpahan nematoda parasit tumbuhan yang tinggi di bagian green dan collar ini mungkin disebabkan oleh kondisi lingkungan pada bagian tersebut sesuai bagi pertumbuhan dan perkembangan nematoda. Bagian green dan collar di PGS merupakan bagian yang dirancang khusus dengan tanah berpasir dan ditumbuhi rumput bermuda (Cynodon dactylon) yang ditanam secara monokultur. Selain ditanam secara monokultur, rumput ini juga mendapat perawatan yang intensif yaitu meliputi penyiraman, pemangkasan, pengenatan dengan pasir halus, dan pemupukan NPK. Rumput bermuda yang dirawat demikian ini tumbuh dengan baik sehingga perakarannya sesuai bagi nematoda parasit tumbuhan sebagai sumber nutrisi. Akar rumput yang kaya nutrisi memacu pertumbuhan populasi nematoda parasit tumbuhan.

Aplikasi pestisida carbofuran butiran secara rutin setiap bulan untuk pengendalian OPT termasuk nematoda pada bagian green dan collar di PGS tampaknya tidak efektif dalam menekan nematoda parasit tumbuhan di kedua bagian ini. Tidak efektifnya aplikasi pestisida ini tampak dari kelimpahan seluruh genus (Gambar2) dan

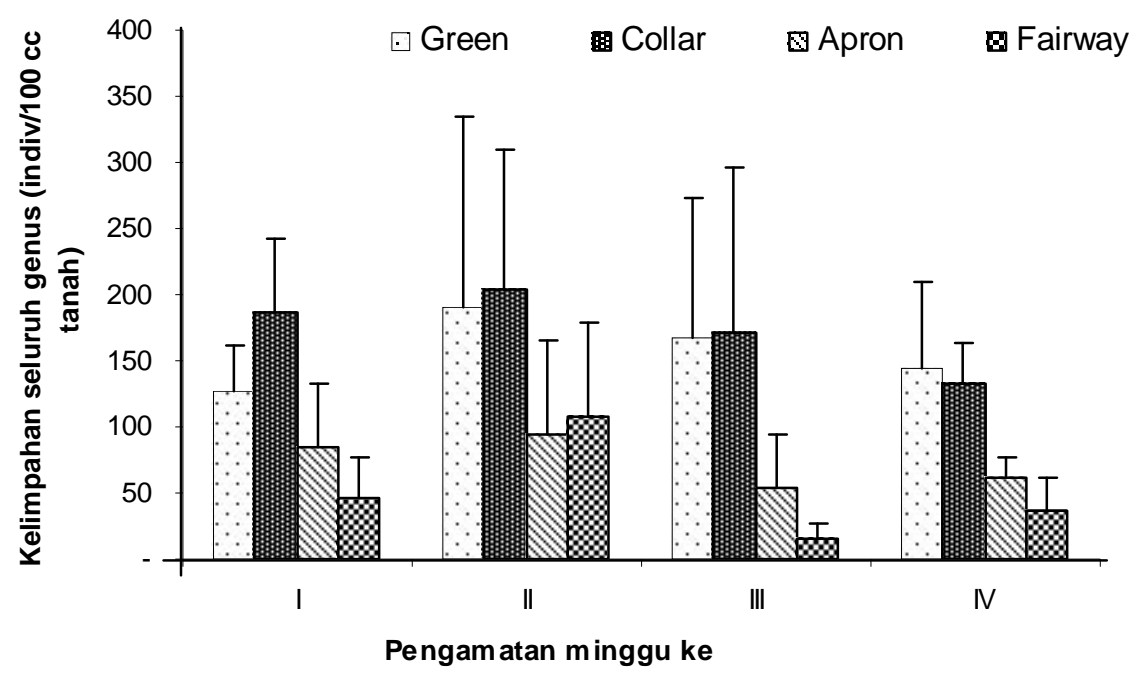

Gambar 2. Kelimpahan seluruh genus nematoda di bagian-bagain hole PGS Bandar Lampung 
Tabel 3. Kelimpahan, keragaman, dan maturitas nematoda pada bagian-bagian hole PGS Bandar Lapung (*)

\begin{tabular}{|c|c|c|c|c|c|c|c|c|c|c|c|c|c|c|c|c|}
\hline \multirow{3}{*}{ Peubah } & \multicolumn{16}{|c|}{ Bagian-bagian hole PGS } \\
\hline & \multicolumn{4}{|c|}{ Green } & \multicolumn{4}{|c|}{ Collar } & \multicolumn{4}{|c|}{ Apron } & \multirow{2}{*}{\multicolumn{4}{|c|}{$\begin{array}{c}\text { Fairway } \\
\text { (rata-rata } \pm \text { std }\end{array}$}} \\
\hline & \multicolumn{4}{|c|}{ (rata-rata \pm std) } & \multicolumn{4}{|c|}{ (rata-rata \pm std) } & \multicolumn{4}{|c|}{$($ rata-rata \pm std $)$} & & & & \\
\hline \multicolumn{17}{|c|}{ Kelimpahan kelompok makan nematoda (individu per $100 \mathrm{cc}$ tanah) } \\
\hline Nematoda parasit tumbuhan & 91,3 & \pm & 39,0 & a & 119,3 & \pm & 25,9 & a & 36,0 & \pm & 29,2 & $\mathrm{~b}$ & 11,3 & \pm & 5,9 & $\mathrm{~b}$ \\
\hline Nematoda pemakan bakteri & 50,3 & \pm & 29,2 & a & 32,3 & \pm & 22,5 & a & 16,2 & \pm & 7,9 & a & 21,0 & \pm & 16,3 & a \\
\hline Nematoda pemakan jamur & 10,0 & \pm & 13,1 & a & 9,7 & \pm & 13,8 & a & 6,8 & \pm & 3,1 & a & 7,5 & \pm & 8,2 & $a$ \\
\hline Nematoda predator & 3,7 & \pm & 3,0 & $\mathrm{a}$ & 11,7 & \pm & 5,9 & a & 7,7 & \pm & 3,0 & a & 7,3 & \pm & 7,5 & a \\
\hline Nematoda omnivora & 1,7 & \pm & 0,0 & $\mathrm{a}$ & 1,0 & \pm & 1,4 & a & 7,5 & \pm & 9,9 & a & 4,3 & \pm & 2,6 & a \\
\hline \multicolumn{17}{|l|}{ Keragaman dan maturitas nematoda } \\
\hline Jumlah genus & 7,4 & \pm & 0,8 & $\mathrm{ab}$ & 8,6 & \pm & 2,0 & a & 6,0 & \pm & 1,5 & $\mathrm{bc}$ & 4,4 & \pm & 1,3 & c \\
\hline Indeks Shannon-Weaver (H') & 1,6 & \pm & 0,2 & $\mathrm{a}$ & 1,8 & \pm & 0,3 & a & $, 1,5$ & \pm & 0,3 & $\mathrm{ab}$ & 1,2 & \pm & 0,2 & $\mathrm{t}$ \\
\hline Indeks maturitas nematoda parasit Tbh (PPI) & 1,9 & \pm & 0,5 & $a b$ & 2,4 & \pm & 0,3 & a & 1,5 & \pm & 0,6 & $\mathrm{~b}$ & 0,6 & \pm & 0,2 & \\
\hline Indeks maturitas nematoda free-living (MI) & 0,8 & \pm & 0,3 & $\mathrm{bc}$ & 0,7 & \pm & 0,3 & $\mathrm{c}$ & 1,3 & \pm & 0,6 & $\mathrm{ab}$ & 1,8 & \pm & & s \\
\hline
\end{tabular}

Keterangan : (*) Perhitungan didasarkan dari data empat kali pengamatan dalam satu bulan; data sebaris yang diikuti oleh huruf yang sama menunjukkan tidak berbeda berdasarkan uji Duncan pada taraf nyata $(\mathrm{P}>0,05)$, analisis statistik menggunakan data yang ditransformasi $\sqrt{(x+1)}$. 
kelimpahan nematoda parasit tumbuhan (Tabel 3) di bagian green dan collar yang lebih tinggi daripada di bagian apron dan fairway. Apakah aplikasi pestisida yang tidak efektif ini dapat menjadi indikasi terjadinya resistensi nematoda terhadap carbofuran? Sebaliknya untuk bagian apron dan fairway, baik kelimpahan seluruh genus (Gambar 2) maupun kelimpahan nematoda parasit tumbuhan (Tabel 3) di kedua bagian hole PGS ini rendah. Kedua bagian yang perawatannya kurang intensif dan ditumbuhi berbagai jenis rumput (yang dominan yaitu rumput kerbau/pahitan = Paspalum conjugatum) mungkin justru menyebabkan eksosistemnya lebih stabil sehingga tidak menyebabkan nematoda parasit tumbuhan menjadi dominan.

Karakteristik bagian-bagian hole PGS juga mempengaruhi keragaman nematoda yang dinyatakan dengan jumlah genus, indeks Shannon-Wiener $\left(\mathrm{H}^{\prime}\right)$, serta indeks maturitas nematoda parasit tumbuhan (PPI), dan indeks maturitas nematoda free-living (MI) $(\mathrm{P}<0,01$, Tabel 3).

Rata-rata (dari 5 ulangan) jumlah genus nematoda yang tinggi ditemukan pada bagian collar yaitu 8,6 $\pm 2,0$ genus sedangkan yang rendah terdapat di bagian fairway yaitu 4,4 $\pm 1,3$ genus. Indeks Shannon-Wiener pada bagian collar yaitu H' $=1,8 \pm$ 0,3 juga nyata lebih tinggi daripada nilai $H^{\prime}$ di bagian fairway yaitu $\mathrm{H}^{\prime}=1,2 \pm 0,2$. Baik jumlah genus maupun indeks Shannon-Wiener di bagian green tidak berbeda dengan di bagian collar. Berdasarkan jumlah genus dan indeks Shannon-Wiener, bagian green dan collar PGS memiliki keragaman genus nematoda yang lebih tinggi daripada bagian fairway, tetapi keragaman yang tidak berbeda dengan keragaman genus di bagian apron. Walaupun keragaman genus di bagian green dan collar lebih tinggi daripada di bagian fairway, ini bukan berarti kedua bagian yang disebut terdahulu bebas dari ancaman nematoda parasit tumbuhan. Susilo (2007) menyatakan bahwa peranan keragaman sebagai penekan ledakan populasi suatu jenis hama bukan ditentukan oleh keragaman jenis biota tetapi oleh besarnya fungsi penekan jenis hama tersebut (adanya musuh alami sebagai komponen dari keragaman yang bersangkutan).

Nilai indeks maturitas nematoda free-living (MI) bagian green $(\mathrm{MI}=0,8 \pm 0,3)$ dan collar $(\mathrm{MI}=$ $0,7 \pm 0,3)$ lebih rendah daripada bagian fairway $(\mathrm{MI}=$ $1,8 \pm 0,5)$. Kedua bagian hole yang disebut terdahulu ini menunjukkan lebih terganggu daripada bagian fairway karena nilai MI nya lebih rendah. Bongers (1990) menjelaskan bahwa indeks MI dan PPI dapat menjadi indikator kualitas ekosistem. Ekosistem terganggu memiliki nilai indeks MI yang rendah. Berdasarkan nilai indeks PPI, bagian green (PPI $=1,9$ $\pm 0,5)$ dan collar $(\mathrm{PPI}=2,4 \pm 0,3)$ produktivitanya lebih tinggi daripada bagian fairway (PPI $=0,6 \pm 0,2$ ). Menurut Bongers (1990), ekosistem yang memiliki nilai indeks PPI tinggi produktivitasnya juga tinggi. Berdasarkan nilai indeks MI dan PPI maka green dan collar merupakan bagian yang lebih terganggu tetapi lebih produktivif daripada fairway. Perawatan yang intensif pada bagian green dan collar mungkin menjadi faktor pengganggu ekosistem tetapi justeru meningkatkan produktivitas tumbuhan terutama rumput bermuda. Sebaliknya untuk bagian fairway, bagian ini kurang mendapat perawatan dan ditumbuhi berbagai jenis rumput lokal (didominasi rumput pahitan) sehingga kurang terganggu tetapi produktivitas tumbuhannya rendah. Gangguan ekosistem di bagian green dan collar mungkin juga disebabkan oleh intensitas intervensi manusia terutama ketika bermain golf karena di bagian inilah terletak hole, yaitu target memasukkan bola golf.

Gangguan ekosistem dan poduktivitas tumbuhan di bagian green dan collar dapat memacu peningkatan kelimpahan nematoda parasit tumbuhan tetapi menekan kelimpahan nematoda free-living. Kondisi sebaliknya terjadi di bagian fairway. Karakteristik komunitas nematoda dapat memberikan indikasi bahwa bagian green dan collar (yang merupakan bagian penting PGS) berpeluang besar mengalami peningkatan kelimpahan namatoda parasit tumbuhan sampai taraf yang dapat menyebabkan kerusakan sehingga menurunkan kualitas rumput. Beberapa genus nematoda yang perlu dipantau kelimpahannya adalah Helicotylenchus, Hoplolaimus, Criconemella, dan Xiphinema. Keempat genus nematoda ini merupakan genus dominan dalam komunitas nematoda.

\section{SIMPULAN}

Dari hasil penelitian ini dapat disimpulkan bahwa Padang Golf Sukarame (PGS) Bandar Lampung dihuni oleh lebih kurang 50 genus yang tergolong dalam 28 famili nematoda. Jumlah genus nematoda parasit tumbuhan lebih banyak daripada nematoda free-living (nematoda nir-parasit 
tumbunanl). Naraktenstıк komumlas nematoda uı bagian-bagian hole PGS berbeda-beda. Kelimpahan seluruh genus dan keragaman genus nematoda di bagian green dan collar lebih tinggi daripada di bagian fairway. Berdasarkan kelimpahan kelompok makan nematoda, indeks maturitas nematoda parasit tumbuhan (PPI) dan indeks maturitas nematoda freeliving (MI), pada bagian green dan $c$

ollar lebih sesuai bagi pertumbuhan dan perkembangan nematoda parasit tumbuhan daripada pertumbuhan dan perkembangan nematoda free-living dan sebaliknya untuk bagian fairway. Empat genus nematoda parasit tumbuhan yang dominan di PGS adalah Helicotylenchus, Hoplolaimus, Criconemella, dan Xiphinema.

\section{SANWACANA}

Peneliti menyampaikan terima kasih kepada Proyek Semi-QUE Depdiknas Tahun 2004 Jurusan Proteksi Tanaman FP Unila yang telah mendanai penelitian ini. Terima kasih juga peneliti sampaikan kepada Bapak Salgio, Pengelola PGS yang telah memberi ijin penggunaan lokasi penelitian dan Bustanil Arifin, S.P. yang telah membantu dalam kegiatan survei dan pengumpulan data.

\section{DAFTAR PUSTAKA}

Bongers, T. \& M. Bongers. 1998. Functional diversity of nematodes. Applied Soil Ecology 10: 239-251.

Bongers, T. 1990. The maturity index: An ecological measure of environmental disturbance based on nematode species composition. Oecologia 83: 14-19.

Crow, W.T., T. Lowe, \& D. Lickfeldt. 2005. Over seeding and nematicides affect sting nematodes in Bermuda grass fairway. (on line) http://www.usga/turf/green section record/200 5/nov-dec/overseeding.html. diakses 16 Juli $\underline{2006}$.

Dropkin, V. H. 1992. Pengantar Nematologi Tumbuhan. (Diterjemahkan oleh Mulyadi dan supraptoyo). Gajani iviaua universily rress, Yogyakarta.

Freckman, D.W. \& C.H. Ettema. 1993. Assesing nematode communities in agroecosystem of varying human intervention. Agruculture, Ecosystem and Environment 45: 293-262.

Goodey, J.B. 1963. Soil and Freshwater Nematodes. Mathuen \& Co Ltd., London., John Wiley \& Sons, INC, New York.

Mai, W.F. \& H.H. Lyon. 1975. Pictorial key to genera of plant-parasitic nematodes. Comstock Publishing Associates, Cornell University Press.

McSorley, R. \& J.J. Frederick. 1999. Nematode population fluctuation during decomposition of specific organic amendment. Journal of Nematology 31(1): 37-47.

SAS Institute, Inc. 1998. SAS/SAT User' Guide. Version 6, Fourth Edition. SAS Institute, Cary, N.C.

Siddiqi, M.R. 1986. Tylenchida parasites of plant and insect. Commonwealth Institute of Parasitology, St. Albans United Kingdom.

Sikora, E. J., E. A. Guertal, \& K. L. Bowen. 1999. Golf course nematodes - The hidden enemy. Highlights of Agricultural Research 46 (3) (online).

http://www.ag.auburn.edu/aaes/communication /highlights/fall99/golf/html. diakses 28 April 2007.

Susilo, F.X. 2007. Pengendalian hayati dengan memberdayakan musuh alami hama tanaman. Graha Ilmu, Yogyakarta.

Tjahjono, B. 2007. Nematoda parasit rumput padang golf di Indonesia. (on line). http//indonesiagcoa.org/articles-isi/Nematoda-rumput.htm. diakses 31 Mei 2007.

Walker, N.R., G. L. Goad, H. Zhang \& D.L. Martin. 2002. Factors associated with population of plant-parasitic nematodes in bent grass putting 
green in Oklahoma. Plant Diseases 66 (7): 764768

Walker, N.R., H. Zhang, \& D.L. Martin. 2005. Potential management approaches for the sting nematode in Bermuda grass sod production. International Turf grass Society Research Journal 10: 793-796.

Wang, Y., R.L. Crocker, L.T. Wilson, G. Smart, X. Wei, W.T. Nailon, Jr., \& P.P Cobb. 2001. Effect of nematode and fungal treatment on non-target turf grass-inhabiting arthropod and nematode population. Environ Entomol. 30(2): 196-203.
Westerdahi, B.B., M.A. Harivandi, \& L.R. Costello. 2005. Biology and management of nematodes on turf grass in Northern California. (on line) http://www.usga.org/turf/green_section_record/ 2005/sep_oct/biology.html. diakses 16 Juli 2006.

Yeates, G.W. 1996. Diversity of nematode fauna under three vegetation types on phallic soil in Otego, New Zealand. New Zealand Journal of Zoology 23: 401-407.

Yeates, G.W., T. Bonger, R.G.M. De Goe, D.W. Freckman \& S.S. Georgieva. 1993. Feeding habits in soil nematode families and genera-an outline for soil ecologists. Journal of Nematology 25(3): 315-331. 